\title{
ВИЗНАЧЕННЯ ФАГОЦИТУВАННЯ ШТАМІВ ЗОЛОТИСТОГО СТАФІЛОКОКА (S. AUREUS), ВИДІЛЕНОГО У ДІТЕЙ, ХВОРИХ НА КІР
}

\section{Визначення фагоцитування штамів золотистого стафрілокока (S. aureus), виділеного у дітей, хворих на кір}

\section{Н. М. Олійник, Н. Я. Кравець}

Тернопільський національний медичний університет імені І. Я. Горбачевського МОЗ України

Резюме. Золотистий стафрілокок - один із найпоширеніших у світі серед збудників інорекційних захворювань. Як відомо, розвитку інфрекції сприяють різні чинники та фрактори вірулентності стафрілококів. Значно менш відомо про їх взаємодію один з одним та захисними механізмами імунної системи господаря. Важливе значення імунокомпетентних клітин у розвитку запального прочесу було підставою для вивчення здатності до фрагоцитування штамів золотистого стафрілокока, виділеного з носоглотки дітей, хворих на кір.

Мета дослідження - визначити здатність до фрагоцитування штамів золотистого стафрілокока, виділеного у дітей, хворих на кір, нейтрофрільними гранулоцитами і моноцитами перифрерійної крові.

Матеріали і методи. Фагоцитарну реакцію оцінювали за допомогою наступних показників: активності фрагоцитозу або відсотка фрагоцитарноактивних лейкоцитів, індексу фрагоцитозу - середньої кількості поглинутих мікробів на один фрагоцит. У процесі дослідження було сфрормовано дві групи: перша - дослідна (35 хворих на кір дітей); друга - контрольна (зразки нормальної мікрофрлори від практично здорових людей - 15 осіб). Матеріал із ротоглотки брали стерильним тампоном, досліджували його бактеріологічним методом. Кількісний склад бактерій відображали у кількості колонієутворювальних одиниць (КУО) в перерахунку на розведення дослідного матеріалу. Ідентифрікацію мікроорганізмів проводили за стандартними схемами. Дослідження фрагоцитозу - за методом Кост і Стенко.

Результати. Під час дослідження було виявлено, що вагому роль у процесі фрагоцитозу відіграють нейтрофрільні гранулоцити. Фагоцитарна активність нейтрофрілів відносно культури S. aureus, виділеної у дітей, хворих на кір, нижча на 46,9 \%, моноцитів - на 38, 8 \% порівняно із групою здорових осіб. Також спостерігалося зниження фрагоцитарного індексу в фрагоцитуючих лейкоцитах відносно культури S. aureus, виділеної у дітей, хворих на кір: нейтрофрілів - на 31,7\%, моноцитів - на 38,6 \%.

Висновки. Зниження здатності до фрагоцитування культури золотистого стафрілокока, виділеної у дітей, хворих на кір, фрагоцитуючими клітинами у до-
Determination of phagocytic activity of $\mathrm{S}$. aureus strains isolated from children with measles

N. M. Oliynyk, N. Ya. Kravets

I. Horbachevsky Ternopil National Medical University

e-mail: kravecnj@tdmu.edu.ua

Summary. S. aureus is one of the world's most common pathogens of infectious diseases. It is known that the development of infection is facilitated by various factors and factors of virulence of staphylococci. Much less is known about their interaction with each other and the protective mechanisms of the host's immune system. The importance of immunocompetent cells in the development of the inflammatory process was the basis for studying the ability to phagocytose strains of Staphylococcus aureus isolated from the nasopharynx of children with measles.

The aim of the study - to determine the ability to phagocytose Staphylococcus aureus strains isolated from children with measles by neutrophilic granulocytes and peripheral blood monocytes.

Materials and Methods. The phagocytic response was assessed using the following indicators: phagocytosis activity or the percentage of phagocytic-active leukocytes, phagocytosis index - the average number of absorbed microbes per phagocyte. During the study, two groups were formed: group 1 - experimental (35 patients with measles); group 2 - control (samples of normal microflora from almost healthy people - 15 persons). The material from the oropharynx was taken with a sterile swab, examined by bacteriological method. The quantitative composition of bacteria was reflected in the number of colony forming units (CFU) in terms of dilution of the test material. Identification of microorganisms was performed according to standard schemes. Phagocytosis studies were performed by the method of Kost and Stenko.

Results. During the study, it was found that neutrophilic granulocytes play an important role in the process of phagocytosis. Phagocytic activity of neutrophils isolated from children with measles and monocytes was less than $46.9 \%$ and $38.8 \%$ compared with the group of healthy individuals. There was also a decrease in the phagocytic index in phagocytic leukocytes relative to the culture of S. aureus isolated from children with measles: neutrophils $31.7 \%$, monocytes - $38.6 \%$.

Conclusions. The decrease in the phagocytic ability of Staphylococcus aureus culture isolated from children with measles by phagocytic cells in the experimental group 
слідній групі, очевидно спричинено наявністю фракторів вірулентності збудника, що суттєво пригнічують фрагоцитоз та зумовлюють здатність мікроорганізмів до тривалої персистенції у середині фрагоцитів.

Ключові слова: золотистий стафілокок; S. aureus; фpaгоцитування; моноцити; нейтрофрільні гранулоцити; індекс фрагоцитозу.

\section{ВСТУП}

Актуальною проблемою у сучасній медицині $€$ зростання кількості інфекційно-запальних процесів, які спричинені умовно-патогенними мікроорганізмами, тобто збудниками гнійно-запальних процесів із низьким ступенем патогенності для людини, що проявляється лише при певних умовах. Інша назва цих збудників - «мікроби-опортуністи». Зокрема, у всьому світі неухильно загострюється проблема інфекцій, викликаних грампозитивними мікроорганізмами. Стаорілококи - збудники значної частини позалікарняних і нозокоміальних бактеремій, пневмоній, інфекцій шкіри та слизових оболонок людини. Близько $20 \%$ відсотків населення - постійні носії золотистого стафрілокока, при цьому бактерія не викликає у них ніяких симптомів. Здорове носійство S. aureus в нижніх носових ходах спостерігається у 70-90 \% обстежених. Для здорової людини стафрілококи, які належать до мікрофрлори її організму, не становлять небезпеки, але в разі зниження реактивності імунної системи, - стають збудниками різних захворювань [2].

Проблема полягає не лише в розповсюдженні й високій частоті виділення S. aureus, a в зростаючому рівні антибіотикорезистентності цього виду бактерій, інтенсивному використанні інвазивних методів діагностики і лікування, значному розповсюдженні серед пацієнтів набутих імунодесріцитних станів різноманітної етіології та різного ступеня тяжкості [1]. Попри те, що S. aureus є одними із найбільш вивчених представників умовно-патогенних мікроорганізмів, він і на сьогодні продовжує викликати увагу спеціалістів різної ланки [3].

Патогенність являє собою багатооракторну полідетермінантну властивість мікроорганізмів. Це генотипова ознака бактерій, френотиповим проявом якої $€$ вірулентність. Фактори патогенності зумовлюють здатність мікроорганізмів протистояти механізмам захисту організму господаря та розмножуватися в ньому. Зокрема, фрактори вірулентності S. aureus суттєво пригнічують фрагоцитоз, зумовлюють здатність збудника до тривалої персистенції у середині фрагоцитів. До них відносять фрактори адгезії (адгезини), які здатні зв'язувати фрібронектин. Поверхневі білки виявляють гідрофробні властивості й забезпечують прикріплення стасрілококів до клітин тканин. Наявність капсули або капсулоподібної (слизової оболонки) субстанції полісахаридної природи притаманні майже усім штамам S. aureus, оскільки гени, що детерміну- is apparently due to the presence of virulence factors of the pathogen, which significantly inhibit phagocytosis and cause the ability of microorganisms to persist for a long time.

Key words: Staphylococcus aureus; phagocytosis; monocytes; neutrophilic granulocytes; phagocytosis index.

ють капсулоутворення, локалізовані на хромосомі. Біологічна активність капсульних полісахаридів визначає їх антифрагоцитарні властивості й полягає в опсонізації інкапсульних стафрілококів, тобто мікрокапсула захищає бактерії від поглинання поліморфноядерними лейкоцитами, сприяє адгезії та розповсюдженню мікроорганізмів у тканинах. Тейхоєві кислоти активують систему комплементу за альтернативним шляхом, а також полегшують адгезію бактерій до епітеліальних клітин і здатні інгібувати поглинальну активність фрагоцитів [3, 4]. Ферменти проявляють різноспрямовану дію: каталаза руйнує пероксид водню, захищає бактерії від токсичних кисневих радикалів, b-лактамаза руйнує молекули b-лактамних антибіотиків, ліпаза полегшує адгезію та проникнення до тканин, зокрема здатна руйнувати сальні «пробки», що полегшує проникнення стафілококів у волосяні фолікули, коагулаза спричиняє згортання плазми крові. Сам фрермент не взаємодіє з фрібриногеном, а утворює тромбіноподібну речовину. Фібринозна плівка, що при цьому утворюється, відіграє роль додаткової капсули, яка захищає бактерії від фрагоцитозу [6].

ще один фрактор захисту клітин S. aureus від дії макроорганізму - це їхня здатність синтезувати пероксидазу, яка перешкоджає фрагоцитозу стафрілококів поліморфно-ядерними нейтрофрілами. Кількість активних лейкоцитів збільшується, а їхня поглинальна здатність знижується. Найбільш виражене зниження хемотаксису та бактерицидної активності фрагоцититів спостерігається при хронічній стафрілококовій інсрекції, зокрема за рахунок синтезу лейкоцидинів та b-токсинів S. aureus. Лейкоцидини (токсин Пантона - Валентайна) порушують водно-електролітний баланс у клітині, викликають деструкцію лейкоцитів людини. Токсин синдрому токсичного шоку (TSST-1 - Toxic Shock Syndrome Toxin) - екзотоксин, який зумовлює розвиток специфрічного симптомокомплексу. Мішені дії TSST-1 - нейтросріли і, можливо, макрофраги [4].

Процес поглинання та інактивації стафрілококів фрагоцитами, значною мірою залежить від температурного режиму та концентрації мікроорганізмів. У разі коливання температури нижче 38 та вище 41 C фрагоцитарна активність знижується, а при температурі $4{ }^{\circ} \mathrm{C}$ дорівнює $6 \%$ проти 96,1 \% такої при $37^{\circ} \mathrm{C}$. При концентрації стаорілококів 10-150 бактеріальних клітин на 1 фагоцит протягом 20 хв поглинається 78-86 \% бактерій; при концентрації 400 клітин на 1 фрагоцит - $56 \%$ [3].
Вісник медичних і біологічних досліджень Bulletin of Medical and Biological Research
$2(8), 2021$ 
Імунна система людини забезпечує їі біологічну індивідуальність та захищає організм від чужорідних агентів, антигенів. Вона представлена комплексом органів і клітин, здатних виконувати імунологічні фрункції, однією із яких є фрагоцитоз. Фагоцитоз належить до вроджених консервативних і постійних імунних процесів в організмі людини. Єдиними клітинами, що володіють активним фрагоцитозом, $\epsilon$ нейтросріли і моноцити, саме тому їх вважають профресійними фрагоцитами. Порівнюючи фрагоцитарні властивості цих клітин, виявилося, що антимікробна здатність нейтрофрілів вище, ніж у макрофагів [1]. Нейтрофрільна відповідь - це сама перша відповідь при гострих запаленнях та інфрекціях і завжди передує більш специсрічній - лімсроцитарній. Нейтрофрільні гранулоцити (НГ) одними з перших зустрічають патогенні та умовно-патогенні мікроорганізми, які проникають через захисні бар'єри організму. Секреція широкого спектра цитокінів надає можливість НГ не тільки впливати на активність інших імунокомпетентних клітин, а також регулювати специфрічну імунну відповідь. НГ займають одну 3 найбільш активних позицій у системі гуморальноклітинної кооперації крові, від їх фрагоцитарної активності залежить елімінація збудника $[7,8]$.

Активною фрагоцитарною фрункцією володіють моноцити. Це найбільші клітини периферійної крові, вони являються макрофрагами, тобто здатні поглинати відносно великі частинки та клітини і, як правило, не гинуть після фрагоцитування. Цим вони відрізняються від мікрофагоцитів, що здатні поглинати відносно невеликі частки і, як правило, гинуть після фрагоцитування.

Важливе значення цих імунокомпетентних клітин у розвитку запального процесу було підставою для вивчення здатності до фрагоцитування золотистого стафілокока, виділеного з носоглотки дітей, хворих на кір. На сьогодні спалахи даного захворювання викликають особливе занепокоєння в контексті ускладнень, що виникають унаслідок зниження імунного статусу під впливом вірусу кору та активізації гноєтворної мікрофлори, зокрема стафрілококової, стрептококової, пневмококової тощо. Стафрілококи $€$ одними із найбільш вивчених представників умовнопатогенних мікроорганізмів, які володіють вираженими інвазивними властивостями, суттєво пригнічують фрагоцитоз, здатні до тривалої персистенції у середині фрагоцитів.

Метою дослідження було визначити здатність до фрагоцитування золотистого стасрілокока, виділеного у дітей, хворих на кір, нейтрофрільними гранулоцитами і моноцитами периферійної крові.

\section{МАТЕРІАЛИ I МЕТОДИ}

Фагоцитарну реакцію оцінювали за допомогою наступних показників: активності фрагоцитозу або відсотка фрагоцитарноактивних лейкоцитів (КФ), індекса фрагоцитозу (ІФ) - середньої кількості поглинутих мікробів на один фрагоцит [5].

У процесі дослідження було сформовано дві групи: перша - дослідна (35 хворих на кір дітей віком від 5 до 17 років); друга - контрольна (зразки нормальної мікрофрлори від практично здорових людей - 15 осіб). Матеріал із ротоглотки брали стерильним тампоном, досліджували його бактеріологічним методом. Кількісний склад бактерій відображали у кількості колонієутворювальних одиниць (КУО) в перерахунку на розведення дослідного матеріалу. Ідентифрікацію мікроорганізмів проводили за стандартними схемами. Дослідження фрагоцитозу - за методом Кост і Стенко. Принцип методу полягає у використанні здатності лейкоцитів поглинати і перетравлювати мікроорганізми для оцінки їх функцціональної активності. Для виготовлення суспензії живих мікроорганізмів у пробірку з одноденною культурою мікробів вносили незначну кількість фрізіологічного розчину, перемішували та переносили розведену культуру мікробів піпеткою у хімічну пробірку. Фізіологічним розчином доводили вміст пробірки до ступеня мутності бактерійного стандарту 1 млрд мікробних тіл в 1 мл. У відалівську пробірку вносили 1 капіляр $4 \%$ цитрату натрію, 2 капіляри крові, 1 капіляр одноденної живої культури з 1 млрд мікробних тіл в 1 мл. Зразки інкубували в термостаті при $37^{\circ} \mathrm{C}$ протягом 1 год. Виготовляли на предметних скельцях тонкі мазки, фріксували та фрарбували за Романовським - Гімзою. У пофрарбованих мазках підраховували 100 лейкоцитів по перифрерії мазка із імерсійною системою. Відмічали відсоток фрагоцитуючих нейтрофілів - показних фрагоцитарної активності та середню кількість мікроорганізмів у кожному із фагоцитуючих лейкоцитів - фрагоцитарний індекс [5].

\section{РЕЗУЛЬТАТИ Й ОБГОВОРЕННЯ}

Результати вивчення здатності до фрагоцитування S. aureus наведені в таблиці. Під час дослідження було виявлено, що вагому роль в процесі фагоцитозу відіграють нейтрофрільні гранулоцити. Фагоцитарна активність нейтрофілів відносно культури S. aureus, виділеної у дітей, хворих на кір, нижча на 46,9 \%, моноцитів - на 38,8 \% порівняно із групою здорових осіб. Також спостерігалося зниження фрагоцитарного індексу в фрагоцитуючих лейкоцитів відносно культури S. aureus, виділеної у дітей, хворих на кір: нейтрофрілів - на 31,7 \%, моноцитів - на 38,6 \%.

Перспективами подальших досліджень $є$ продовження вивчення особливостей фрункціонування клітинної ланки неспецифрічної резистентності організму залежно від вираженння патологічного процесу. 
Таблиця. Результати вивчення здатності до фрагоцитування S. aureus

\begin{tabular}{l|l|c|c|c}
\hline \multirow{2}{*}{ Фагоцитуюча клітина } & \multicolumn{1}{|l|}{ Показник } & Одиниця виміру & $\begin{array}{c}\text { Хворі на кір } \\
(\mathrm{n}=35)\end{array}$ & $\begin{array}{c}\text { Практично здорові особи } \\
\text { (контрольна група) } \\
(\mathrm{n}=15)\end{array}$ \\
\hline \multirow{2}{*}{ Нейтросріли } & Фагоцитарна активність & $\%$ & 54,3 & 79,8 \\
\cline { 2 - 5 } & Фагоцитарний індекс & ум. од. & 5,8 & 7,7 \\
\hline \multirow{2}{*}{ Моноцити } & Фагоцитарна активність & $\%$ & 55,4 & 76,9 \\
\cline { 2 - 5 } & Фагоцитарний індекс & ум. од. & 6,1 & 8,7 \\
\hline
\end{tabular}

\section{ВИСНОВКИ}

Зниження здатності до фрагоцитування культури золотистого стафрілокока, виділеної у дітей, хворих на кір, фрагоцитуючими клітинами у дослідній групі, очевидно спричинено наявністю фракторів вірулентності збудника, що суттєво пригнічують фрагоцитоз та зумовлюють здатність мікроорганізму до тривалої персистенції у середині фрагоцитів.

\section{СПИСОК ЛІТЕРАТУРИ}

1. Абул К. Аббас Основи імунології: фрункції та розлади імунної системи : навч. посіб. / Абул К. Аббас, Ендрю Г. Ліхтман, Шив Піллай - пер. 6-го англ. вид. [наук. ред. пер.: Чоп'як В.] - К. : ВСВ «Медицина», 2020. - 328 с.

2. Анохин В. А. Стафилококовая инфекция у детей и подростков / В. А. Анохин // Практическая медицина. 2008. - № 7(31). - С. 8-14.

3. Веклич К. А. Елімінація вірусу кору: вирішення питання та майбутні виклики / К. А. Веклич // Міжнародний медичний журнал. - 2019. - № 3. - С. 83-88.

4. Характеристика стафрілококів та їх роль у патології дітей / М. А. Гарисруліна, О.С.Воронкова, Т. М. Шевченко, А. І. Вінніков // Вісник Дніпропетровського університету. Біологія, медицина. - 2014. - № 5 (9)12. - С. 115-120.

5. Лабинская А. С. Общая и санитарная микробиология с техникой микробиологических исследований :

\section{REFERENCES}

1. Abul KAbbas, Andrew HH. Lichtman, and Shiv Pillai Basic Immunology 6th Edition. Elsevier; 2020.

2. Anokhyn VA. [Staphylococcal infection in children and teenagers]. Prakt med. 2008;7(31): 8-14. Russian.

3. Veklych KA. [Elimination of the measles virus: solving the issues and future challenges]. Mizhnar med. 2019;3: 83-8. Ukrainian.

4. Haryfulina MA, Voronkova OS, Shevchenko TM, Vinnikov Al. [Characteristics of staphylococci and their role in pathology of children]. Visn Dnipropet univer: Biol, med. 2014;5(9)12: 115-20. Ukrainian.

5. Labynskaia AS, Blynkova LP, Eshchyna AS. General and sanitary microbiology with the technique of microbiological research: textbook. manual, 4-ed. [Общая и санитарная микробиология с техникой микробиологических исследований: уч. пособие] Moscow: Lan-Press; 2020. Russian. уч. пособ. - 4-изд. / А. С. Лабинская, Л. П. Блинкова, А. С. Ещина. - М. : Лань-Пресс, 2020. - 592 с.

6. Сравнительная характеристика гуморального имунного ответа у больных ангинами и иноекциями мягких тканей стафилококковой (группы а) этиологии / Д. А. Клейменов, Е. В. Глушкова, Н. Ф. Дмитриева [и др.] // Медицинский альманах. - 2012. - № 3. - С. 144-147.

7. Холодна Л. С. Імунологія : підручник / Л. С. Холодна, Г. А. Любченко, Д. М. Говорун. - К. : ВПЦ «Київський університет», 2017. - 350 с.

8. Bhattacharya $G$. Exposure to sub-inhibitory concentrations of gentamicin, ciprofloxacin and cefotaxime induces multidrug resistance and reactive oxygen species generation in meticillin-sensitive Staphylococcus aureus / G. Bhattacharya, D. Dey, S. Das, A. Banerjee // J. Med. Microbiol. - 2017. - Vol. 66 (6). - P. 762-769.

6. Kleimenov DA, Hlushkova EV, Dmytryeva NF, Eshchyna AS, Tymofeev YuM, Aksenova AV, et al. [Comparative characteristics of the humoral immune response in patients with tonsillitis and soft tissue infections of staphylococcal (group a) etiology]. Med alman. 2012;3: 144-7. Russian.

7. Kholodna LS, Liubchenko HA, Hovorun DM. Immunology: a textbook. [Імунологія: підручник] Kyiv: VPTs, Kyiv University; 2017. Ukrainian.

8. Bhattacharya G, Dey D, Das S, Banerjee A. Exposure to sub-inhibitory concentrations of gentamicin, ciprofloxacin and cefotaxime induces multidrug resistance and reactive oxygen species generation in meticillin-sensitive Staphylococcus aureus. J Med Microbiol. 2017;66(6): 7629. Available from: https: // doi.org/ 10.1099/jmm.0.000492.

Отримано 09.04.21 